Ксенија Кончаревић

Универзитет у Београду

Филолошки факултет

Катедра за славистику

kkoncar@mts.rs
УДК 821.163.41.09(=161.1)

https://doi.org/10.18485/slavistika.2020.24.1.8

Оригинални научни рад примљено 02.11.2019.

прихваћено за штампу 21.05.2020.

\title{
РУСИЈА И РУСИ У СРПСКОЈ МЕМОАРИСТИЦИ 1917-1927.
}

У раду се разматрају најкарактеристичнији наративи о руској култури настали у српској средини од 1917. до 1927. године. У овом циљу анализирали смо 22 текста мемоаристичке литературе поникла из пера истакнутих културних и јавних делатника, као и добровољаца у Црвеној армији из Србије и српских земаља. Размотрена је у првом реду перцепција културе свакодневног живота, као и измена најкарактеристичнијих представа о Русији и Русима у односу на претходно раздобље (XVIII и XIX век), а то су аспекти који нису били предмет досадашњих истраживања.

Кључне речи: руска култура, српска мемоарска литература 1917-1927, култура свакодневног живота, смена стереотипа о Русији и Русима.

The aim of this paper is to investigate the most prominent narratives regarding Russian culture that appeared between 1917 and 1927 . We analyzed 22 examples of memoiristic literature that were written by prominent cultural and public figures, as well as from the volunteers of the Red Army stationed in Serbia and other territories populated by Serbs. The paper focuses on the culture of everyday life, as well as on the shift in the most prominent perceptions of Russia and Russians in comparison to the period of 18 th and 19th centuries - aspects that to date have not been the subject of investigation.

Keywords: Russian culture, Serbian memoiristic literature 1917-1927, culture of everyday life, change of stereotypes about Russia and Russians.

Почетком XX века Русија је доживела драматични преображај. То доба било је испуњено необично узбудљивим догађајима: индустријска криза 1900-1903, праћена таласом великих штрајкова и демонстрација радништва и сељаштва, Руско-јапански рат 1904-1905, прва руска револуција 1905-1907, улазак у Први светки рат 1914, објава рата Отоманској империји исте године, Фебруарска револуција 1917. и пад династије Романових, формирање двеју привремених коалиционих влада на челу са кнезом Г. Ј. Љвовом, односно А. Ф. Керенским, успостављање совјетске власти од 25. октобра (7. новембра) 1917. до марта 1918. по читавој земљи, грађански рат који ће потрајати до 1920 , носећи са собом смрт, болести, беду, незапосленост, неизвесност, рационисану потрошњу, проглашење „нове економске политике“ 1921. и, десет година по доласку совјета на власт, почетак колективизације на селу и разрада првог петогодишњег плана, што означава прелаз на командно-директивну економију. Све су ово догађаји који су обележили време у коме су српски интелектуалци, а

* Рад је настао у оквиру пројекта Православног богословског факултета Универзитета у Београду „Српска теологија у XX веку: фундаменталне претпоставке теолошких дисциплина у европском контексту - историјска и савремена перспектива“, који финансијски подржава Министарство просвете и науке Републике Србије (евиденциони број пројекта ОИ 179078). 
потом и добровољци који су ступали у одреде Црвене армије, долазили у Русију и одатле слали писма својим пријатељима, или дописе својим редакцијама, или су се касније сећали свога боравка у Русији. Међу осамнаест мемоариста чије смо текстове обрадили (в. Извори) могу се наћи и неколико њих који су добро познати нашој историографији и култури - Милош Московљевић, Мирослав Спалајковић, Никола Груловић, Станислав Винавер, Драгиша Васић, Сретен Стојановић, Родољуб Чолаковић, Иван Шајковић.

У претходном раду заснованом на мемоарској грађи (Кончаревић 2019) показали смо да се у XVIII веку највише инсистирало на сличностима двају народа и њихових историјских путева. Међу Србима тога доба доминирају представе о „великом православном цару“, заштитнику Срба и свих Словена, што је у бити представљало трансформацију давнашње идеје о Москви као „трећем Риму“. По запажању Мирослава Јовановића, Срби у XVIII веку заправо су имали „мултипликовани идентитет“" (Јовановић 2011: 19), али је такав феномен могао имати значајну улогу у процесу изузетно брзе асимилације Срба који су се током тога века у два наврата, из Војводине и Далмације, организовано пресељавали у Русију. Наредни век, иако је оточео и знатним делом протицао у знаку романтизма и борбе српског народа за еманципацију, за аутономију а потом и независну државу, доноси трансформацију глобалне слике о Русији, у којој има више места за уочавање разлика и за усложњавање перцепције Русије из два међусобно све удаљенија и све супротстављенија дискурса - из перспективе славенофилске оданости, али и латентне русофобије са западњачким коренима. „Тај дубоки раскол у односу према Русији и перцепцији Русије остао је константа српског друштва до данас, само што се временом све више радикализовао“, закључује Јовановић (Jovanović 2010: 11-17). Раздобље које анализирамо у овоме раду, као што ћемо показати, карактерише се даљим продубљавањем амбивалентних ставова према Русији и њеној култури, а тежиште се, са имагинарне географије, фасцинације простором, Црквом, туристичког дискурса и стереотипног виђења Руса, помера на реалистички опис животне свакодневице, покушаје тумачења узрока и домета револуције, њеног карактера, утемељености револуционарних превирања у етнопсихологији и карактерологији Руса, и, не на последњем месту, на промишљање могуће улоге руских избеглица у српском друштву.

У данима револуције и грађанског рата у Русији се, према наводима историчара, нашло око 30000 Југословена, од којих су неки у ову земљу доспели послом, као дипломате, трговци, чиновници, студенти, док се већина обрела на Источном фронту као припадници аустроугарске армије, одакле су пребегавали у руске јединице и формирали добровољачке јединице (Očak 1990: 209-232). Српски мемоаристи чија сведочанства овде анализирамо били су различитих политичких и идеолошких одељења, имали су неједнак ниво образовања, потицали из разних средина - и све ће се то рефлектовати на њихове импресије о крају империје и почетку једног новог друштвеног поретка.

Непосредна сведочанства о првим данима револуције, са обиљем чињеница из непосредно виђеног и доживљеног, али и из штампе и дипломатских извоpa, пружа Милош Московљевић, филолог који је радио при српском посланству у Петрограду. Његове дневничке белешке из Русије историчар Момчило Исић окарактерисао је као превасходно фактографско сведочанство, „али ис- 
товремено и многодимензионално, употпуњено 'душом', покаткад и емоционално обојено“ (Исић 2007: 8). У својим белешкама за 25. октобар, и поред запажања о увођењу цензуре на више листова и претњи смртном казном свима који се противе наредбама револуционара, он констатује: „Како сва ова руска револуција иде „вјало“, без живота, крви, темперамента, апатично, млитаво! Синоћ на једном месту неки војник чита прокламацију бољшевика, где се говори о захвату власти, а сва публика мирно слуша и разилази се, без речи протеста, или одобравања, без икакве дискусије. На другом опет месту по прочитању сви узвикују: Хвала Богу! Све је добро, само кад се свршило без крви!“‘ (372)1 Сутрадан он износи мишљење да „бољшевики (sic!) немају потпуну власт и виде да су сви слојеви скоро против њих, а други су по инерцији или апатији уз њих“ (373). Дана 27. октобра он отворено увиђа да се бољшевици осећају несигурно, да прете погромима, забрањују слободну штампу, ,а у свему томе служе се несавесном демагошком агитацијом, основаном на лажи, златним брдима, клеветама“ (373). Већ 29. октобра Московљевић усликује: „Да ли је ово последњи дан бољшевичке авантуре?“ (375), да би сутрадан резигнирано констатовао: „Ни данас се не сврши бољшевичка авантура; напротив, сада је узела опасне размере, постала права оргија. Док је јуче ујутро изгледало да су свршили своје, увече су они постали потпуни господари ситуације, а данас, кад сам прочитао новине видео сам да за своје злочине, по свему изгледу, не само неће бити кажњени, него ће придобити уза се и остале социјалисте““(376). Он са ужасом описује покоље које је огранизовао Револуционарни војни комитет, крваве борбе између артиљерије Керенског и бољшевика у предграђима Петрограда, бележи велики број жртава у московском Кремљу и околини (око две хиљаде), и уздајући се у „издржљивост и тврдоглавство англосаксонске расе“ и Јапана, верује у слом бољшевизма, „али ћу до коначне победе још неколико оваквих свезака исписати“ (378).

Милутин Велимировић нашао се у доба револуције у Москви, где је, по његовом казивању, било у то време око 30 наших студената. Прикључио се са већином од њих Првој српској добровољачкој дивизији, која је претходно ратовала у Добруџи, а у Москви се нашла ради лечења и опоравка, Године 1918. они полазе за Владивосток, до кога путују месец дана. Велимировић оставља сведочанства о тежини пута, о солидарности наших добровољаца, о пустоши у руским градовима. Наводи да су руске власти, пошто се број Срба у Владивостоку стално повећавао, свима понудиле настањење око Благовешченска и реке Амура, и да је око две хиљаде њих пристало на колонизацију и остало заувек на Далеком истоку, док су остали, укључујући и Велимировића, преко француског посланства из Пекинга превежени у Европу и упућени на Солунски фронт (379-381).

Никола Груловић, који у политику улази као члан Социјалдемократске партије Димитрија Туцовића, а од 1918. као организатор југословенског одреда Црвене гарде, што ће ући у састав Првог комунистичког југословенског пука Црвене армије, био је српски добровољац из Срема који је пребегао из ау-

\footnotetext{
${ }^{1}$ Бројеви у заградама означавају странице на којима се налазе цитати у Јовановићевој Антологији (в. Извори).
} 
строугарске армије. Он најпре доспева у Лавов, а затим преко Кијева, Полтаве, Харкова, Пензе, Самаре, Уфе, Чељабинска и Кургана, у заробљенички логор у Петропавловску. И поред околности у којима се обрео, он не може да не запази лепоте „велеграда“ Лавова, трг са величанственом стилском зградом железничке станице, да се не диви „некадашњем главном и престоном граду старе Русије“" Кијеву, Крешчатику, Печерској лаври, Дњепру. На путу кроз Русију Груловићеву пажњу привлаче таљиге и начин запрезања коња (руска тројка), одела руских сељака и сељанки, за које (женске ношње) примећује сличност са ношњом из околине Београда и са призренским везом (381-382). По доласку у Петропавловск, њега са групом сабораца упућују на радове у Тургајско-уралској области. Становало се у „привременим кућицама од бусења, тзв. земљанкама“, спавало на поду, на слами, али народ се показао „гостољубив и странца ретко пушта из куће док га не угости““ (383). Груловић учествује у октобарским догађајима на страни револуционара, сведочећи о борби Југословена на страни Црвене гарде у Москви, Петрограду и Кијеву, а потом у редовима Српскосовјетског батаљона у Царицину, који је на њега оставио непријатан утисак због општег сиромаштва и чемерног призора „радничких насеља с малим кућерцима, збијеним једни уз друге као палидрвца у кутији“ (388). О грађанском рату сведочанства остављају и српски добровољци пребегли из аустроугарске армије, сви из Војводине: Данило Чекић, који се са сународницима бори у Чапајевљевој дивизији (392-394), Жарко Табаковић у Саратову и Москви (397-400), Јован Черевички, који војује на фронту против петљуроваца у Украјини, а потом одлази у Саратов и Самару, где служи у „продовољственом пуку“ (интендатури) (395-397), Гаја Ранисављевић у Сибиру (400-407), Мане Кнежевић, који проводи пет година у Осмој литванској дивизији и Јован Д. Миланковић, који износи своје успомене из Сибира 1918-19. и описује пут у домовину 1920. Поред драгоцених података о фронтовским збивањима, наши добровољци остављају и сведочанства о свакодневици у годинама грађанског рата и револуције. Гаја Ранисављевић пренеражен је посвемашњом бедом у Сибиру: људи иду од куће до куће и просе - „прекрсте се и моле за парче хлеба“ (400), јер су „сви трговци затворили своје радње, а сељаци нису хтели да продају храну - била је велика глад“ (у Краснојарску и околини); болница и Иркутску, у коју је упућен на лечење, „била је врло слабо опремљена: слаба исхрана, мало лекова“ (401). Иако се бори на страни совјетских власти, Ранисављевић са ужасом приповеда о реквирирању хране и других потрепштина, упадању у села, убијању и злостављању народа, не либећи се ни описа зверстава која су уследила као реакција на црвени терор: „Било је случајева да кулаци убију чланове комисије, распоре им стомак и стрпају сланину и разну другу храну говорећи: 'Ево вам сад хране, наједите се'“ (403). Односе у редовима црвеноармејаца он идеализује, сравњујући их са гвозденом дисциплином у војсци којој је претходно припадао: „Војник је био слободан да пита официра шта хоће, а овај је био дужан да му све објасни. Тако није било у аустроугарској војсци. С руским војником је лепо и лако командовати. Он је послушан, пожртвован и дисциплинован“ (403). Код Јована Д. Миланковића налазимо описе велике скупоће и несташице робе у Харкову и Тули. У Пензи је било много боље, због добро снабдевене пијаце: „Пенза је имала свој варошки папирни новац, неке хартијице које ван града нису имале никакву вредност“ (412). У Самари влада „бољшевичко расуло“, а 
наши војници ту једу „ужасан хлеб, као земља испуцан, влажан, црн, тежак, са много сламе, песка и пепела“ (413). Ипак, и у таквим условима у Самари 1918. наш приповедач, иначе официр, слави своју крсну славу, св. Ђорђа: „Уместо свештеника, сам сам извршио обред црквени: резао колач, читао молитве и тропар, спремио кољиво, запалио свећу пред иконом“, чему је погодовала околност што је тада становао код једног старијег Руса, који је стално страховао за свој живот - „тип руског трговца; у свакој соби по једна икона: сваки дан метанише и сви певају црквене песме“ (414). Пред Петровдан доспева у Чељабинск, који је био центар наше војне и националне организације, и ту учествује на првој скупштини (југословенског) Народног већа и присуствује концерту који је у локалном позоришту одржан у корист наших инвалида (421).

Станислав Винавер, који се у Русији 1917. обрео послом, обављајући информационо-дипломатске и послове превођења, показује доста симпатија за совјетски режим. „Бољшевици уништаваху често могућности живота, али раде све што могу, за високу културу <...>. У буђењу рускога народа, бољшевици му не ометају његову жеђ за културом <... , само се живи тешко оним животом првобитним, који омогућава све остало“ (442).

Од непосредних сведочанстава још су драгоценија промишљања о карактеру, узроцима, дометима руске револуције. Поручник Љубомир МихајловићПољски за себе сведочи да је у данима револуције и грађанског рата у Русији „остајао само брат, гост, иностранац, Југословен који нема права да се меша а још мање учествује у тој крволочној, нечовечној међусобној борби за власт“ (424). Као непристрасан посматрач он износи суд да је „револуција крвава стихија хаоса у коме се, и код 'најкултурнијих створова', буди и распламћује у буру онај сакривени у човеку инстинкт звера, пред чијом крволочношћу, свирепошћу и скотством бледе сви најнижи инстинкти правих дивљих зверова“. И даље: „Револуција у Русији је грозна, развратна, крвава, одвратна, лажљива, неправична: у њој нема идеала, нема светиња, нема људи“ (425). У Ростову „варош је била мртва. Оне стотине хиљада људи, жена и деце, чији су се жагор и смех још јуче чули на све стране, као да су изумрли. На површину је изашла периферија, гладна, сурова, готова на све. <..> Један подлац сарањивао је по неколико невиних породица одједанпут. Хватали су сакривене „контр-револуционаре“. Извлачили су их из сандука, испод прљавог веша, из куфера, ормана, из подрума, са тавана. Покривене брашном, замазане угљем, страшне, јадне, смешне“ (426-427). Своју књигу Крвави трагови: крај једне империје: револуција и грађански рат у Русији (Београд, 1933) он доживљава као „кандило свима оним подављеним, исеченим, унакаженим, растргнутим, спаљеним, измученим жртвама ове најкрвавије, најжешће, најодвратније борбе за власт" (425).

Мирослав Спалајковић, посланик Краљевине Србије у Русији пре и за време Првог светског рата, покушава да руску револуцију сагледа са етнопсихолошког, моралног, социолошког и политичког гледишта. У најкраћем, он узроке револуције види у „органском анархизму нераздвојном раси коме су се додали елементи криминалитета и атавичког алкохолизма <... >. Из свију тих разлога, руска револуција је била само општи delirium tremens, у току кога је немогуће констатовати нормално и разумно дело“ (436). Свим вођама руске револуције, 
по Спалајковићу, својствени су „интелектуална утопија, морални мистицизам или неотпорност злу, расипање у економском пољу, хипертрофија артистичког осећања, атрофија политичког смисла и несазнавање стварног интереса“ (436). Бољшевизам је за њега, који је био присутан у свим њеним моментима од 1917. до 1919, „све видео и све преживео“ (435), „најгори апсолутизам, најцрња тиранија“, „олигархија лудака, злочинаца и дегенерисаних“, „самовољна и апсолутна влада незнања, лењости, порока и злочина“", „диктатура најнижих нагона човека“ (438). Године 1919, када пише своју књигу, Спалајковић се пита: „Да ли Лењин схвата страховито значење за будућу демократску Русију оне луде фабрикације новчаница, која представља јамачно за све Русе без изузетка једнакост беде? Да ли он зна да спрема на тај начин за будуће нараштаје најсуровије економско ропство, које ће трајати неколико десетина година, а за руски пролетаријат повишење рада и беде у корист пролетаријата свих других земаља? То је највећи Лењинов злочин“ (438). Иако је изношењем ових претпоставки аутор књиге Драма Русије: бољиевички рај показао невероватну економску проницљивост, он на једном месту попушта пред емоцијама и веровањем да ce „Голгота Русије примиче своме крају“ и да ће „благодарећи снази и младости свога организма, неисцрпним материјалним и моралним својим изворима, Русија ускоро изићи из критичне фазе болести која би, за сваки други народни организам, била вероватно смртна“ (440).

Узроцима руске револуције бави се и Иван Шајковић. „За руску револуцију и њене страшне последице“, пише овај аутор 1927. године, „криви су, на првом месту, они слепци <..> који су се плашили школе и просвете народне, који су кнутом 'памет утеривали', који су мислили да могу вечито да гњече а да отпора не дочекају“ (490). „У Русији су требали да воде рачуна како ће да се избегне револуција, још пре сто година - чим су се појавили 'декабристи'. Требало је народ постепено ослободити од ропства и тираније, дати му човечанска права и слободу, просветити га у духу хришћанско-философских идеја најбољих руских људи“(491).

Драгиша Васић, припадник „грађанске левице“ (републиканац), у Русији се, заједно са Владиславом Рибникаром, младим директором „Политике“ и угледним вајаром Сретеном Стојановићем, обрео десет година после револуције на прослави десетогодишњице октобарског преврата и успостављања совјетске власти. Анализирајући Васићев однос према Русији, историчар Мира Радојевић констатује да је он био „понекад загрцнут од љубави коју је осећао према сабраћи, а понекад и разочаран, јер је сан о Русији био лепши од стварности“" (Радојевић 2015: 83), те да је, „непрестано узбуђен, надражених нерава и преплављен утисцима“, можда видео и „оно чега није било“ (Радојевић 2015: 85). У Москви он уочава препуне трамваје, бољшевичке пароле и разгласе који емитују говоре званичника, а најтеже му пада то што су цркве претворене у музеје, што се руше капеле; задржава се на призору старог свештеника који је принуђен да проси (450) и описује како су „свуда неизбројна клатна била у истом ставу ћутања, а тамо, под Кремљом, у маузолеју од дрвета, налазила се она рука што их је зауставила“ (452). Васић оставља сведочанство о болници у Павловском и о оближњој касарни, као и о образовању на Универзитету, изражавајући задовољство виђеним (454-463). Петроград на њега оставља мучан утисак „на- 
прегнуте заузетости око животнога опстанка“ (467). Он констатује „потпуну економску дезорганизацију и глад“, и запажа „како бескрајна празнина духа зјапи на све стране“, будући „окамењен оном пустошном празнином у којој се душа нигле није могла осетити“ (468). Супротно Васићу, Сретен Стојановић, који се истовремено са њим обрео у Русији, поздравља совјетски поредак, пишући у о њему са знатном дозом идеализације: „Све је пробуђено, све је позвано на рад и сваком су указани путеви којима ће најпре да стигне до већег благостања и у материјалном и у културном погледу. Ја сам стално имао утисак, посматрајући комунисте, да су они жртве. Они су натоварили на себе страшан терет, пробудили су масама апетит за бољим, и уз сарадњу маса пружају им све и отварају врата за све што је добро“, премда „има комуниста који експлоатишу свој положај и корумпирају се. Случајеви корупције већином се објављују, али ако су у случају и комунисти и борци из револуције, често се догађа да прво иду пред комунистички суд“, где су казне „оштрије и немилосрдније“ (474). Стојановић посећује музеје, изложбе и скоро све културне институције које су отворене посетиоцима, диви се културном уздизању радника, као и тобожњој транспарентности свих информација: „Комунисти ће вас пустити свуда и свакоме. Допустиће вам да све чујете и о свему се обавестите код кога желите, али ће вам помоћи и да проверите тачност ваших података“ (475). Констатује да су уз совјетску власт „сви учитељи“, „готово сва техничка интелегенција“ и „велики део лекара по селима“ (477). Од негативних утисака не прећуткује да „радници много пију“, ,али комсомолци ретко који, а пионири, <...> та дечица која држе зборове и отварају седнице и конференције, та деца не пију и надају се да никада неће ни пити“ (477). Идеализована слика Совјетске Русије врхунац налази у запажању: „Они су успели да уздрмају цео свет, засадили су клицу свуда и постали су центар. Ви осећате да је Москва центар света...“ (478).

Најзад, има аутора који су се у контекступоследица револуције бавили и проблемом прихвата и ангажовања руских избеглица. Већ 1921. Љуба Јовановић у чланку Руси у нас, објављеном у „Новом животу“, књ. 6, св. 2, констатује „тешкоће које подносимо због ових наших гостију: они нас коштају, заузимају станове по нашим и без тога тескобним градовима и местима, поскупљују нам, где год их дође већи број, наш и иначе скупи живот“ (491). Позитивну страну доласка више од тридесет хиљада руских емиграната види у томе што је већина њих, изузев неколико хиљада војника, из „горњих слојева рускога друштва; у тима је један део онога што је Русија понајбољег имала у погледу културнога развитка, школовања, научне и друге стручне спреме“ (492). Он уочава да образовани емигранти „оскудицу наших посленика добро попуњавају у нашој државној служби“, посебно у болницима, ортопедским заводима, на катастарском премеравању Србије, у војним установама, у приватним предузећима, у многим школама и другим просветним заводима, а нарочито на универзитетима, али да међу њима има још доста неупослених књиговођа, инжењера свих врста, архитеката, агронома и других привредника (493). Јовановић с горчином констатује да је „од наших Руса само мали број прионуо да створи себи каку поузданију могућност за колико толико нормално живљење, а још је мање оних који су се прихватили да заснују неку нову, ма колико привремену егзистенцију. $<\ldots .>$ Сва им је мисао управљена на што скорији повратак у Русију, наравно у 
онакву Русију какву свак сам жели и замишља““ (493). Он резигнирано шише о одлуци професора Медицинског факултета у Београду који су одбили да за своје сараднике приме руске професоре (напоменућемо да је то била само прва реакција, а да су касније и на медицинском факултету, и у здравственом систему Србије били примљени истакнути руски лекари - укупно њих 190, исп. Милошевич, Москвин 2012: 22), али да су неки руски професори ангажовани на разним катедрама свих осталих факултета у Београду, Загребу, Љубљани, Суботици и Скопљу. Јовановић са усхићењем говори и о потенцијалима руских уметника који су се обрели у емиграцији, а свој оглед завршава речима: „Ови људи представљају знатним делом понајсавршеније примерке онога што је руски културни живот израдио у свом историјском развитку“ (494). Иван Шајковић у књизи Руски проблем (Београд, 1927) такође увиђа психолошку баријеру руских емиграната која се огледа у томе што „главна потка целе њене мисаоне сфере и делатности јесте: незадовољство. Банкари, трговци, велепоседници, кућевласници - незадовољни су што су изгублили своја имања <...; бивши генерали, министри, високи чиновници и њихове осиротеле господђе плачу за изгубљеном положајем и значајем у „вишем свету“; просветни и друштвени радници оплакују изгубљене аудиторије и разне могућности кориснога рада $<\ldots .>$. Све је то природно“ (495). Шајковић увиђа и подељеност руске емиграције по политичким опредељењима, што је додатно слаби (496). „Ми не треба да заборавимо“, закључује Шајковић, „да нам Руски Народ преко своје емиграције и сада доноси користи и донео би још и веће, кад бисмо ми многе њене силе, које пропадају, правилно искористили. Треба дати могућности што већем броју руских научника и специјалиста на разним пољима културног рада да оставе што боље и што дубље трагиве у нашем животу. <...> За све то треба јасан, зрео програм, какога, на жалост, све до сада нисмо имали. Такође и руска емиграција треба озбиљније да схвати своју мисионарску улогу и да од ње не бежи. Напротив, она треба да је испољи са много више иницијативе него до сада“ (497).

У целини посматрано, у српској мемоаристици 1917-1927. знатно је мања пажња посвећена руској култури у њеним разноврсним манифестацијама него у претходним раздобљима. Веома су ретки наративи о архитектури градова (само код Николе Груловића и Јована Д. Миланковића), потпуно изостају они о духовности, сакралној архитектури и ентеријеру храмова, богослужбеној пракси, невербалној сакралној комуникацији, етикецијским нормама и традицијама, култури исхране, што је било доминантно у мемоаристици XVIII и XIX века. Очевици грађанског рата и револуције пажњу посвећују детаљима из животне свакодневице, која је у револуционарном преврату потпуно измењена и сведена на пуко преживљавање, рационисану исхрану, отимање имовине и залиха од кулака, неред и несташице на тржишту, несигурност међу становништвом. Већина мемоариста не остаје равнодушна на слике револуционарног терора ликвидације, мобилизацију и цензуру штампе не одобрава нико од српских мемоариста. Наративи о посвемашњем сиромаштву и глади најизараженији су код Срба из Војводине, мобилизованих на Источни фронт и пребеглих из аустроугарске војске. Пошто је Војводина у односу на ужу Србију и пре, и за време Првог светског рата живела у знатно већем благостању, не чуди нас изразито негативна обојеност казивања о свакодневном животу обичног грађанства 
и сељаштва код мемоариста из средине за коју је и иначе, по запажањима етнопсихолога и карактеролога, карактеристичан „опортунизам, конформизам, задовољство цивилизацијским нивоом живота, оним што данас називамо животним стандардом“ (Јеротић 2001: 142). Тек десет година касније, учесници прославе јубилеја Октобарске револуције 1917. Станислав Винавер и Светислав Стојановић позитивно пишу о културним манифестацијама и просвећивању радника, што објашњавамо пре свега чињеницом да су српски културни делатници, обилазећи Совјетску Русију у саставу званичних делегација или по позиву Компоунистичке партије и Коминтерне, били лишени могућности да стекну увид у реални живот нижих друштвених слојева у урбаној средини, а да су им села и варошице тада, десет година од избијања револуције, у већини случајева остали terra incognita. Најзад, општа благонаклоност према Русији и руском народу морала је и сада, у радикално измењеним условима, утиснути снажан печат на доживљај руске стварности.

\section{Цитирана литература}

Исић, Момчило. „Уводне напомене“. [У:] Момчило Исић (прир.) Милош Московљевић. У великој руској револуцији. Дневничке белешке. Београд: Институт за новију историју Србије, 2007, 7-52.

[Isić, Momčilo. „Uvodne napomene“. [U:] Momčilo Isić (prir.) Miloš Moskovljević. U velikoj ruskoj revoluciji. Dnevničke beleške. Beograd: Institut za noviju istoriju Srbije, 2007, 7-52]

Јеротић, Владета. Србија и Срби између изазова и одговора. Београд, Бањалука: Ars Libri, Бесједа, 2001.

[Jerotić, Vladeta. Srbija i Srbi između izazova i odgovora. Beograd, Banjaluka: Ars Libri, Besjeda, 2001]

Јовановић, Мирослав. „О „Две Русије“ у српском друштву или Русија „за унутрашњу употребу“: слика Другог као идентитетско самодефинисање“. [У]: Мирослав Јовановић (прир.) Срби о Русији и Русима: од Елизавете Петровне до Владимира Путина. Антологија. Београд: Православни богословски факултет Универзитета: Институт за теолошка истраживања: Институт за новију историју Србије, 2011, $11-42$.

[Jovanović, Miroslav. „O „dve Rusije“ u srpskom društvu ili Rusija „za unutrašnju upotrebu“: slika Drugog kao identitetsko samodefinisanje“. [U]: Miroslav Jovanović (prir.) Srbi o Rusiji i Rusima: od Elizavete Petrovne do Vladimira Putina. Antologija. Beograd: Pravoslavni bogoslovski fakultet Univerziteta: Institut za teološka istraživanja: Institut za noviju istoriju Srbije, 2011, 11-42]

Кончаревић, Ксенија. „Руска култура у српској мемоаристици XIX и XX века“. Славистика 23/1, 2019: 213-222.

[Končarević, Ksenija. „Ruska kultura u srpskoj memoaristici XIX i XX veka“. Slavistika 23/1, 2019: 213-222]

Милошевич, Миладин, Виктор Москвин (ред.). Российские врачи в Королевстве сербов, хорватов и словенцев/ Югославии. Библиографический словарь и анкеты (1918-1946). Белград - Москва: Дом русского зарубежья им. Александра Солженицына, 2012. 
[Miloševič, Miladin, Viktor Moskvin (red.). Rossijskie vrači v Korolevstve serbov, horvatov i slovencev/ Ûgoslavii. Bibliografičeskij slovar' i ankety (1918-1946). Belgrad - Moskva: Dom russkogo zarubež'â im. Aleksandra Solženicyna, 2012]

Радојевић, Мира. „Драгиша Васић и Совјетска Русија“. Зборник Матице српске за историју 92, 2015: 77-91.

[Radojević, Mira. „Dragiša Vasić i Sovjetska Rusija“. Zbornik Matice srpske za istoriju 92, 2015: 77-91]

Jovanović, Miroslav. „Dve Rusije o dva dominantna diskursa Rusije u srpskoj javnosti“. U zb.: Ž. Petrović (prir.) Odnosi Srbije i Rusije na početku XXI veka. Beograd, 2010: $1-17$.

Očak, Ivan. „Jugoslavenska vanpartijska emigracija u SSSR-u između dva rata“. Radovi Zavoda za hrvatsku povijest Filozofskog fakulteta u Zagrebu 23, 1990: 209-232.

\section{Извори}

Јовановић, Мирослав (прир.) Срби о Русији и Русима: од Елизавете Петровне до Владимира Путина. Антологија. Београд: Православни богословски факултет Универзитета: Институт за теолошка истраживања: Институт за новију историју Србије, 2011.

[Jovanović, Miroslav (prir.) Srbi o Rusiji i Rusima: od Elizavete Petrovne do Vladimira Putina. Antologija. Beograd: Pravoslavni bogoslovski fakultet Univerziteta: Institut za teološka istraživanja: Institut za noviju istoriju Srbije, 2011]

\section{Ксения Кончаревич}

\section{РОССИЯ И РУССКИЕ В СЕРБСКОЙ МЕМУАРИСТИКЕ 1917-1927}

\section{Резюме}

В предлагаемой работе рассматриваются наиболее характерные нарративы о русской культуре, возникшие в сербской среде с 1917 по 1927 год. В этих целях нами проанализированы 22 текста мемуаристики выдающихся культурных и общественных деятелей Сербии и сербских земель, а также сербских добровольцев в рядах Красной армии. Рассмотрено, в первую очередь, восприятие культуры повседневной жизни, а также изменение наиболее характерных представлений о России и русских в сравнении с предыдушим периодом (XVIII и XIX вв.). Данные аспекты не являлись до сих пор предметом научных исследований. В статье показано, что период с 1917 по 1927 год характеризуется дальнейшим усугублением амбивалентных взглядов сербов на Россию и ее культуру, причем фокус переносится с мнимой географии, очарованности пространством, Церковью, туристического дискурса и стереотипов о русской ментальности на реалистическое описание повседневной жизни, попытки толкования причин и следствий революции, а также ее характера, обоснование революционных событий отличиями национальной психики и чертами характера русских, осмысление роли русских беженцев в сербском обществе и пр.

Ключевые слова: русская культура, сербская мемуаристика 1917-1927, культура повседневной жизни, изменение стереотипов о России и русских. 